Article

\title{
The Political Economy of EU Climate and Energy Policies in Central and Eastern Europe Revisited: Shifting Coalitions and Prospects for Clean Energy Transitions
}

\author{
Stefan Ćetković ${ }^{1, *}$ and Aron Buzogány ${ }^{2}$ \\ ${ }^{1}$ Environmental and Climate Policy Chair, Bavarian School of Public Policy, Technical University of Munich, 80333 Munich, \\ Germany; E-Mail: stefan.cetkovic@hfp.tum.de \\ 2 Institute of Forest, Environmental and Natural Resource Policy, University of Natural Resources and Life Sciences, 1180 \\ Vienna, Austria; E-Mail: aron.buzogany@boku.ac.at \\ * Corresponding author
}

Submitted: 17 October 2018 | Accepted: 24 January 2019 | Published: 28 March 2019

\begin{abstract}
The countries of Central and Eastern Europe (CEE) have commonly been regarded as climate and energy policy laggards blocking more ambitious EU decarbonization targets. Although recent literature has increasingly acknowledged the differences in national positions on energy and climate issues among these states, there has been little comprehensive evidence about their positioning on EU climate and energy policies and the domestic interests which shape government preferences. The article addresses this gap by tracing the voting behavior of six CEE countries (Poland, Hungary, Czech Republic, Slovakia, Bulgaria, and Romania) on EU energy-related legislation in the Council of Ministers between 2007-2018. The article shows that the contestation of energy policies, particularly of climate-related legislation, in the Council of Ministers has increased over time and that these six CEE countries have indeed most often objected to the adoption of EU legislation. The CEE states do not, however, have a common regional positioning on all EU energy policies. Voting coalitions among the six CEE countries differ substantially across energy policy areas. The lack of a common regional position and changing national preferences have enabled the adoption of a relatively ambitious EU Energy and Climate Package for 2030. The differences in national voting patterns are explained by the evolving interests and the ability of key domestic political and economic actors to adapt to and explore benefits from the ever-expanding EU energy and climate policies.
\end{abstract}

\section{Keywords}

Central and Eastern Europe; Council of Ministers; domestic interests; energy transition; Energy Union; EU climate policy; EU energy; illiberalism; Visegrad states

\section{Issue}

This article is part of the issue "EU Energy Policy: Towards a Clean Energy Transition?", edited by Kacper Szulecki and Dag Harald Claes (University of Oslo, Norway).

(C) 2019 by the authors; licensee Cogitatio (Lisbon, Portugal). This article is licensed under a Creative Commons Attribution 4.0 International License (CC BY).

\section{Introduction}

During the last decade, formulating a common and comprehensive European Union (EU) energy policy has required the traversing of a long and bumpy road. EU member states have incorporated their previously independently pursued policy goals of energy security, energy market integration, and decarbonization under a single framework with the publication of the Energy
Union Strategy in 2015 (Szulecki, Fischer, Gullberg, \& Sartor, 2016). Among the different policy dimensions of the Energy Union, energy sector decarbonization has been the most dynamic but also the most contested policy area (Skjærseth, Eikeland, Gulbrandsen, \& Jevnaker, 2016). The EU's climate and energy policy framework was first enacted in 2009 laying out the 2020 goals in the areas of energy efficiency, renewable energy, and greenhouse gas emissions reductions. The latter was to be 
achieved mainly through the Emission Trading Scheme (ETS). The EU has made considerable progress in meeting its 2020 climate and energy targets, triggering farreaching policy change at the national level (Jörgens \& Solorio, 2017). However, the difficulties in policy implementation and the opposition from domestic vested interests have led to increasing resistance among some member states against further expansion of EU energy and climate policy and more ambitious post-2020 targets. The six Central and Eastern European (CEE) countries (four Visegrad countries: Poland, Hungary, Slovakia and Czech Republic, together with Bulgaria and Romania) in particular have been described as climate and energy policy laggards opposing stricter EU goals in the decarbonization of the energy sector (Braun, 2014; Skjærseth, 2018).

Despite growing national reluctance, the adoption of the bold ETS reform and several pieces of legislation under the 2030 climate and energy framework during 2018 signify a deepening and broadening of EU integration in this area. The new EU energy efficiency target has been set to $32.5 \%$ (up from the original $27 \%$ agreed in 2014) and the new Renewable Energy Directive features a 32\% EU target (up from 27\% agreed in 2014) together with the EU-wide regulation which grants a preferential treatment for prosumers and community-owned projects (European Parliament, 2018a, 2018b). Even if the lack of national renewable energy targets is clearly a setback compared to the 2009 Renewable Energy Directive, a new governance mechanism for the Energy Union has been put in place to ensure effective monitoring and policy implementation at the national level (Council of the EU, 2018a). The policy process has thus been a relative success, particularly in view of the modest ambition and political saturation signaled by the European Council in 2014 (General Secretariat of the Council, 2014). This raises the question about the reasons behind the recent positive policy developments and the lessons to be drawn for the future of the Energy Union and national clean energy transitions.

Given that the six CEE countries have been the main opponents of EU energy and climate policies, we expect that the progress in EU energy and climate integration has been related to the weakening of the common position among the six CEE countries in this policy field. While earlier literature rarely differentiated among CEE countries and their energy sectors and suggested that they share a homogeneous view on EU energy and climate issues (Ćetković \& Buzogány, 2016; Skjærseth, 2016; Skjærseth et al., 2016), differences within this group have been acknowledged more recently (Bocquillon \& Maltby, 2017; Mišík, 2017; Nosko \& Mišík, 2017). However, no comprehensive evidence has been offered so far on the national positions of the CEE countries on EU energy and climate policies, how these have changed over time, their implications for EU decision-making, and possible reasons behind the stability and change in national positions.
We argue that different national adaptation capacities, in terms of ability and willingness of domestic energy business interests and governments in the six CEE countries to adapt to the new incentives and opportunities offered by different EU energy and climate policies, have led to the divergence of interests and weakening of a common regional position. This, in turn, has made policy progress at the EU level more politically feasible. To test our assumption, we analyze the voting patterns of the six CEE governments in the Council of Ministers (the Council) in the period 2007-2018. We are particularly interested in climate-related energy legislation (e.g., ETS reform, renewable energy, energy efficiency) but we also consider legislations in other energy-related issue areas, such as energy air pollution or energy security, to obtain a comprehensive picture. In the first step, we ask whether the six CEE governments have indeed increasingly objected to EU energy legislation in the Council and whether the six CEE governments have displayed a common or diverging voting behavior across different energy issue areas. In the second step, we offer some evidence on the reasons behind the common and/or diverging voting patterns of the six CEE countries by focusing on domestic vested interests and drawing on the insights from political economy and energy transitions studies.

The article advances the understanding of EU climate and energy policy integration and the role of the six CEE governments in affecting EU climate and energy efforts while also contributing to the broader literature on decision-making and policy change in the EU. Furthermore, we draw policy-relevant conclusions from the interplay between EU policies and domestic structures for the future prospects of the Energy Union and of national clean energy transitions.

\section{Theoretical Framework}

\subsection{Post-Accession Decision-Making in EU Energy and Climate Policy}

With the eastern enlargement having almost doubled the number of EU member states, decision-making in the EU Council was expected to become more complicated or to leave EU institutions gridlocked (Börzel \& Buzogány, 2019; Hertz \& Leuffen, 2011). A decade later, the evidence remains mixed. Some argue that eastern enlargement has led to a new East-West cleavage in the Council (Mattila, 2009) and that different factors, such as vote weight, budget benefits from the EU, or government positions (left-right, EU integration), are driving voting behavior in old and new member states (Hosli, Mattila, \& Uriot, 2011). Other authors note that the paralysis in EU decision-making that was awaited as a result of eastern enlargement did not materialize (Hagemann \& de Clerck-Sachsse, 2007; Parízek, Hosli, \& Plechanovová, 2015; Toshkov, 2017). While the success of pre-accession conditionality or post-accession socialization might partially explain this, the new member states' policy prefer- 
ences were unclear or matched already existing conflict lines within the Council. Adding to this, institutional solutions, such as delegation to lower echelons of decisionmaking, have helped to avoid gridlock (König \& Junge, 2009; Parízek et al., 2015).

More attention is needed related to the issuespecific preferences guiding governments' voting behavior (Bailer, Mattila, \& Schneider, 2015; Høyland \& Hansen, 2013; Mühlböck \& Tosun, 2017). This reinforces arguments made by liberal intergovernmentalist scholarship that member states seek to protect their regulatory systems from costs incurred on them by EU law and that governmental positions mostly reflect key economic players' interests (Moravcsik, 1993; Naurin, 2018). While these positions might be covered by partisan differences as reflected in governments' left-right orientations, sectoral perspectives should provide more nuanced views on conflict in the Council (see Mühlböck \& Tosun, 2017; Roos, 2018).

The literature provides some evidence that the level of conflict along the East-West divide is higher for environmental, energy, and climate change policies than in other policy fields. In his examination of general patterns of EU-level decision-making, Toshkov (2017) found no evidence of new conflict lines emerging after eastern enlargement, but pointed to emerging differences regarding environmental and climate policies as well on migration issues. Case studies also suggest that energy policy has been a policy field where CEE countries "developed quite clear sets of preferences..., contrary to many other issues where they have very limited or no preferences at all" (Mišík, 2015, p. 6) and have watered down climate and energy policy initiatives at the EU level by opposing stronger regulations (Braun, 2014; Ydersbond, 2018). Changes in EU agendas have partially occurred to accommodate the concerns of CEE states (Bocquillon \& Maltby, 2017; Skjærseth, 2018). Bocquillon and Maltby (2017) show that, even though there is strong internal coordination in the region and increasing opposition towards EU climate and energy policies, the CEE states nevertheless cannot be regarded as a homogeneous block in the shape and intensity this opposition takes.

While much of the literature suggests that CEE countries are likely to converge in contesting ambitious EU climate and energy goals, in this article, we build on work by Bocquillon and Maltby (2017) in that we trace the possible differences in national positions and divergence in voting patterns among the six CEE countries. We advance the debate by not only extending the temporal perspective to the decade 2007-2018, but also by including different policy dimensions in the "interrelated sectors of EU energy and climate change" (Bocquillon \& Maltby, 2017, p. 88) as witnessed in the Council's voting records. The existing literature offers only scarce knowledge about the reasons behind the diverging positions of the six CEE governments on EU energy issues. We seek to close this gap by paying closer attention to the key domestic interests and their evolution. In the following sec- tion, we highlight how domestic energy structures and interests might explain decision-making at the EU level.

\subsection{Political-Economy and Domestic Climate and Energy Preferences in CEE}

Following the seminal work of Hall and Soskice (2001) on 'Varieties of Capitalism' (VoC), scholarly attempts have been made to expand the binary typology differentiating between Liberal Market Economy (LME) and Coordinated Market Economy (CME). For the CEE region, Nölke and Vliegenhart (2009) identified a distinct type of political economy which they termed Dependent Market Economy (DME). The development model of DMEs is primarily driven by foreign capital and the exceptional role of transnational corporations (TNCS) moving their product assembling activities to CEE countries, attracted by their low labor costs, relatively skilled workers, and favorable tax regimes. In addition, DMEs have significantly lower transparency, more centralized decision-making, higher political party clientelism, and higher corruption levels than in Western Europe, undermining the governing capacity of the state and its ability to purposefully engage in transforming the domestic economy (Innes, 2016).

The political-economic model of CEE countries is matched by the similar structures of their industrial and energy systems. Previous research has shown that the DME model has produced dysfunctional patterns in promoting new low-carbon technologies (Ćetković \& Buzogány, 2016). Nevertheless, the commonalities among DMEs should not divert attention from important cross-country differences both in terms of the broader political-economic landscape, but especially concerning the institutions, interests, and material base of the energy sector. While the VoC framework offers important insights into the institutional structure and logic of the six CEE economies, different strands of the political economy literature make us attentive to national- and sectorspecific vested interests and institutions as key factors affecting domestic political processes and their international implications (Katzenstein, 1976). One key insight borrowed from these approaches is that the inherited socio-political structures and vested economic interests will resist or at least try to modify policy reforms that go against domestic interests. The literature on sustainability transitions and socio-technological transformation in the energy sector also emphasizes the role of prevailing interests, ideas, and resources which form the so-called socio-technological regime in the energy sector (Kern, 2011). These approaches highlight the stable, path-dependent nature of energy regimes, which therefore require endogenous or exogenous pressures in order to enable socio-technological change (Lockwood, Kuzemko, Mitchell, \& Hoggett, 2017). As implied by the literature on multi-level reinforcement (Schreurs \& Tiberghien, 2007), the EU has an in-built affinity towards ever-ambitious climate and energy policy, and the ability of reluctant national interests to resist this pro- 
cess might be constrained by the powerful coalition of 'environmental leaders', the Council's consensus-seeking culture, or side-payments received in other policy areas. Another crucial point, elaborated upon in the literatures on policy feedback and policy diffusion, is the dynamic and self-reinforcing nature of the policy process itself. Although negative policy implementation experience can deter national actors and augment policy resistance (Skjærseth, 2018), previously implemented EU policies are also likely to create unanticipated benefits (Skogstad, 2017) which in turn can affect domestic preferences and power-constellations and, ultimately, accelerate policy change.

In sum, whereas the less technologically and economically advanced energy sectors in the six CEE countries are not likely to embrace more ambitious EU energy and climate policies, a more differentiated response by domestic actors is to be expected over time. We expect that the ability of national energy regimes to adapt to and to embrace new energy and climate policies is contingent upon a number of factors in both the state and market spheres. On the state side, energy policy priorities and the ability of the state to impose them on the energy sector are central. In DMEs, governments are particularly concerned with energy security and affordability of energy prices for the industry and households. While the state's ability to steer the clean energy transition is limited and the risk of policy capture by domestic vested interests is high, the dependence on foreign investments may motivate these governments to embrace the EU policy framework and to open the market in new low-carbon sectors. The recent 'illiberal' trend that has gained ground in some CEE countries like Poland and Hungary (Appel \& Orenstein, 2018; Buzogány, 2017) provides further insights into the role states can play in shaping the energy transition. Democratic backsliding and creeping authoritarianism are related to the dependence of these countries on foreign firms and capital as well as the domestic elites' efforts to counter this through regaining control over 'strategic' political and economic resources (Scheiring, 2018). To the extent that illiberal tendencies prevail in the region, this may imply less openness towards foreign investments in renewable energy projects and increasing state influence over the energy sector. On the market side, the concentration of domestic energy business interests, their economic and technological capacity to take advantage of new energy and climate policies, as well as the level of the technological lock-in in fossil-fuel energy sources, should all be key economic factors determining governmental positions towards EU energy and climate policies.

Overall, the literature suggests that national governments and energy sectors will be under increasing pressure to adapt to the evolving EU energy and climate policies and that dynamic state-market constellations will determine national preferences on a given policy issue. Although preference formation at the national level is likely to vary across policy issues, in general we expect that strong illiberal trends, higher dependence on conventional fossil-fuels, and more concentrated and less adaptive capacity on the part of domestic energy industries are likely to lead governments to oppose or abstain from energy legislation in the Council.

\section{Research Design and Data}

This contribution investigates the six CEE countries' positions on EU energy legislation based on voting behavior in the Council. As already noted, the energy policy field under the framework of the Energy Union is relatively broad and includes several different policy dimensions (security, affordability, sustainability) as well as multiple policy areas. For the sake of comprehensiveness, in our analysis, we consider all EU legislation related to the energy sector, including that which does not relate directly to the core issues of the Energy Union, such as air pollution from energy combustion. We also include sustainable transportation policies, as they are tightly linked to EU energy decarbonization measures. A broader view on different energy-related policy areas allows for a more robust comparison and gives insights into the variations of voting behavior and the possible interests behind these.

We use the data on voting on Council decisions published in the Council Secretariat's 'Monthly Summary of Council Acts' reports. Council voting records are widely used in the literature studying national positions and influence in decision-making (Hosli et al., 2011; Mattila, 2004; Toshkov, 2017). Although many issues are typically settled among EU institutions and actors before official voting in the Council takes place, previous research has shown that governments regularly use their votes in the Council to express their disagreement with the agreed legislation as a signal to both domestic and EU-level actors (Hagemann, Hobolt, \& Wratil, 2017). With the expansion of common EU energy policy across different policy areas, we expect to find growing polarization and increasing numbers of dissenting votes. The analysis of the Council's voting records thus allows for tracing the voting-behavior of the six CEE countries over time and the level of regional homogeneity across policy issues.

As most decisions in the Council are adopted with unanimous support, we focus on those cases where Member States voted 'no' or abstained from voting. Following the common practice in the literature, we count abstentions and outright 'nos' together, as the Member States are often thought to avoid publicly opposing the majority. The timeframe for our analysis runs from 2007 to 2018, marking the first decade when all six CEE states were full members. Given that the latest available Monthly Summary of Council Acts is from June 2018, we cover the remaining period through 2018 by referring to individual voting records available on the Council website. Our sample of countries includes the four Visegrad states (V4), which joined the EU in 2004, as well as Romania and Bulgaria, which joined in 2007, and allows us to account for the possible influence of the date of accession 
on the voting behavior of the country. The six CEE countries were selected given their close coordination of positions on EU energy issues (Visegrad Group, 2014), their broadly acknowledged reluctance towards more stringent EU energy and climate policy, and their similarity in terms of their economic models (Ćetković \& Buzogány, 2016). Thus, we are interested in whether, in such a seemingly homogeneous block of countries, convergence or divergence in voting behavior on EU energy issues can be detected and to what extent domestic preferences might help to explain the countries' voting patterns.

\section{Analysis}

\subsection{Voting Behavior in the Council}

Altogether, in the period 2007-2018, we identified 67 decisions adopted by the Council on energy issues. Of these 67 decisions, 23 were adopted without unanimous support. A list of these decisions is provided in the Appendix. We are interested in the dynamics of energy policy-making during the last decade and focus both on member state positions and on coalitions. The coalition behavior of member states provides information on the existence of similar preferences, even if similar voting positions might be based on different reasons. In our data on voting in the Council, $39 \%$ of the decisions were contested by a single state, $35 \%$ by coalitions of two or three states, and $26 \%$ by coalitions with four or more members.

The analysis of the Council's voting records shows that the six CEE countries have indeed most often been members of the 'coalition of unwilling', either by directly opposing or by abstaining from the majority position in the Council on energy issues. However, not only is this trend a relatively recent phenomenon which began in 2013, but, in addition, not all six CEE countries have objected to EU legislation on the same energy policy issues. Figure 1 displays the total number of adopted pieces of energy legislation in the studied period next to the number of pieces of energy legislation adopted without unanimity. The relative number of bills adopted without unanimity has increased since 2015. Here, the comparison between the year 2009 (adoption of the EU energy and climate policy package 2020) and the year 2018 (adoption of the EU energy and climate package 2030) is particularly illustrative. While in 2009 only one out of 13 pieces of legislation failed to reach unanimous support, in 2018 only three out of nine bills were adopted by unanimity.

Figure 2 shows the number of dissenting votes of EU member states for each year, differentiating between the six CEE countries and other EU member states. Between 2007-2012, the six CEE members did not object to any single piece of EU energy legislation adopted by the Council. While there are several likely reasons for this, including the relatively low salience of energy and climate issues and the insufficient political power of CEE countries as new members of the EU, two probable central explanations are that the common EU energy and climate policy was initially not particularly ambitious and CEE countries were able to receive concessions on many important issues.

In the subsequent period 2013-2018, 17 Council decisions which were taken regarding energy legislation fea-

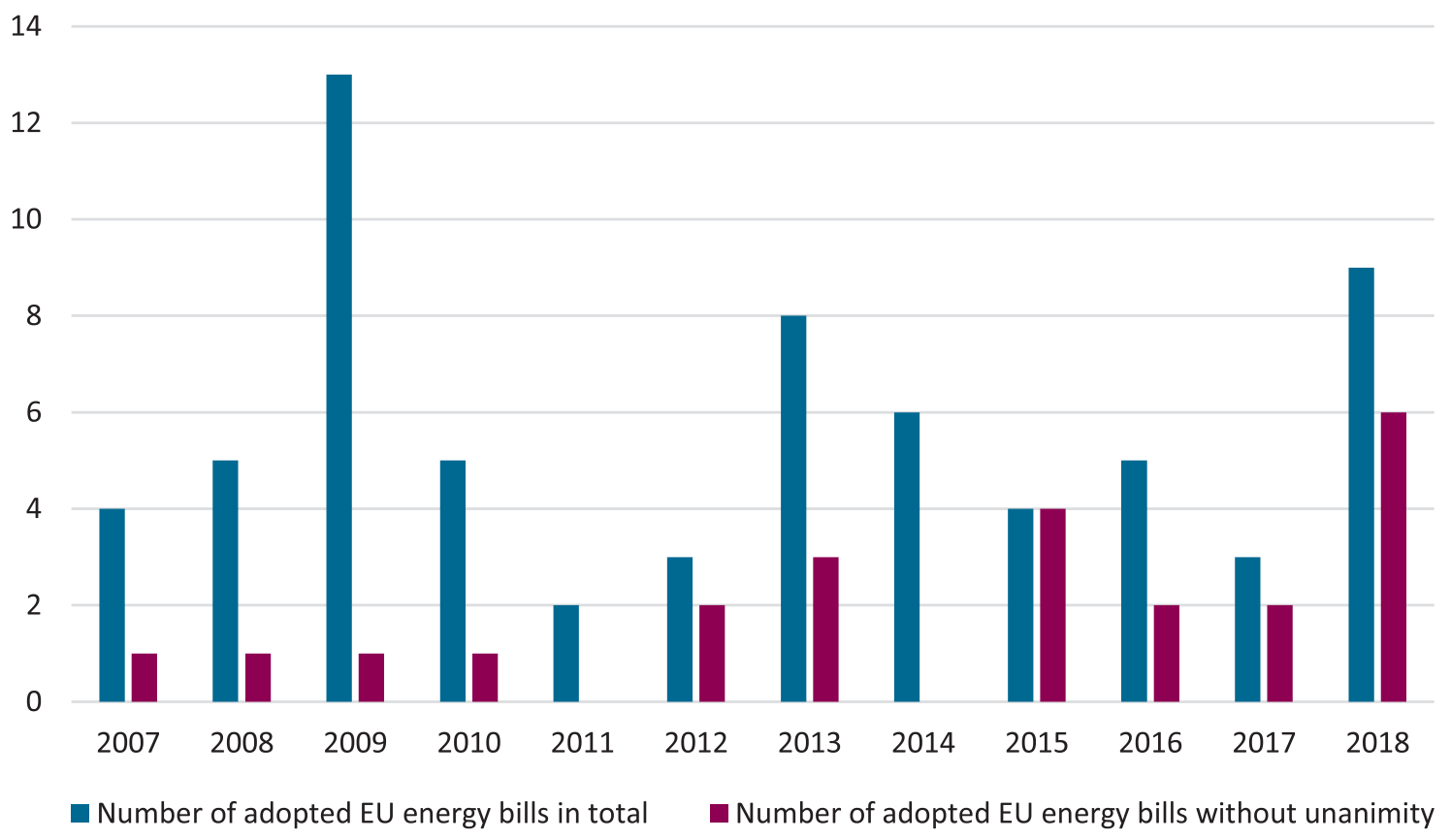

Figure 1. Total number of adopted EU energy legislative acts and the number of energy legislative acts adopted without unanimity in the period 2007-2018. Source: Authors' calculation based on data from the Monthly Summary of Council Acts (https://www.consilium.europa.eu). 
12

10

8

6

4

2

0

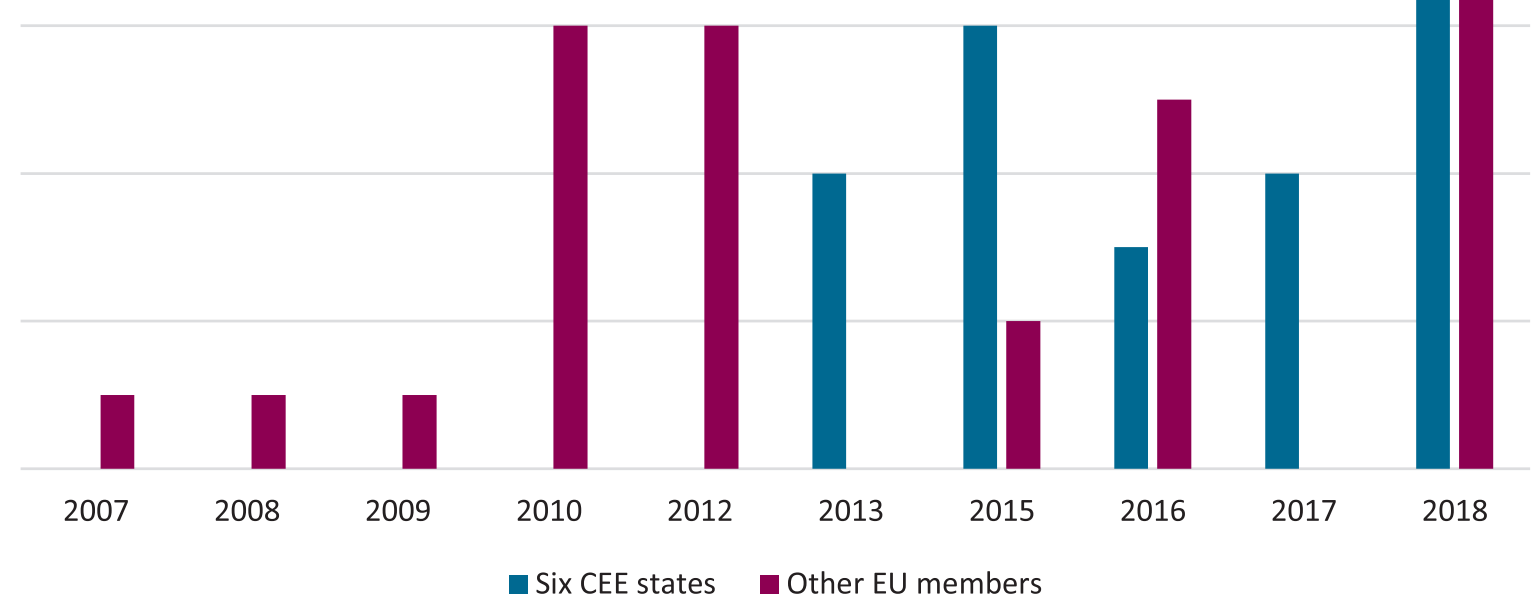

Figure 2. Number of dissenting votes of EU members on EU energy legislative acts in the period 2007-2018. Source: Authors' calculation based on data from the Monthly Summary of Council Acts (https://www.consilium.europa.eu).

tured at least one abstention or a negative vote by a member state. Of 17 cases adopted without unanimity, 16 involved at least one of the six CEE countries. Poland has been the most prominent in objecting to the majority position in the Council by participating in 10 out of 17 cases. Hungary objected seven times, Romania, Slovakia, Czech Republic three times, and Bulgaria twice. No distinctive trend can be noted between 'older' CEE EU members (V4) and 'newer' ones (Bulgaria and Romania). Poland and Hungary have consistently featured among the dissenting voting group while other CEE members have dissented less frequently.

Figure 3 depicts coalitions in the Council using social network analysis. Nodes in the network represent countries while edges between them stand for commonly voiced dissent. Countries with connections to many dissenters are located at the center of the graph, while countries that often form coalitions of dissent together are closer to each other. The size of the nodes shows the frequency of dissent, while the different colors stand for the six CEE and 'other' member states. From Figure 3, it becomes clear that there is a regional pattern of dissent, with Poland, and to a lesser extent Hungary, playing a central role. They are followed by several other CEE countries. Interestingly, Slovakia and the Czech Republic are on the margins of this network of dissenters. Another much smaller and disconnected network of dissenters includes Germany, Finland, Estonia, Spain, and Portugal.
To grasp the potential differences in governments' positions across different policy issues, we identified five main issue areas among the contested legislation documents: 1) GHG emission reductions and ETS reform, 2) air pollution, 3) renewable energy promotion, 4) energy efficiency, and 5) others, which do not belong to any of the mentioned categories including, for instance, a decision on the EU gas supply strategy or state aid for coal mines. We are particularly interested in the dissenting votes of the six CEE countries across issue areas. This data is presented in Figure 4. Overall, climate-related energy legislation has been most often contested by some of the six CEE governments alongside the legislation on air pollution related to energy production. Legislation on GHG emissions reductions, with seven cases, has dominated the energy policy issues on which the six CEE countries abstained or opposed the majority position in the Council. Poland has been involved in all of the seven cases, while Hungary joined in on two occasions and Romania and Bulgaria each joined once in 2015. Air pollution has been the second most controversial issue, with three cases in total. Poland, Romania and Hungary objected to air pollution legislation twice and Bulgaria once. On renewable energy promotion, three Council decisions have been reached without unanimity, one objected to by Poland and Hungary, the second by the Czech Republic, and the third by the Czech Republic, Slovakia, and Hungary. Energy efficiency legislations have been opposed 

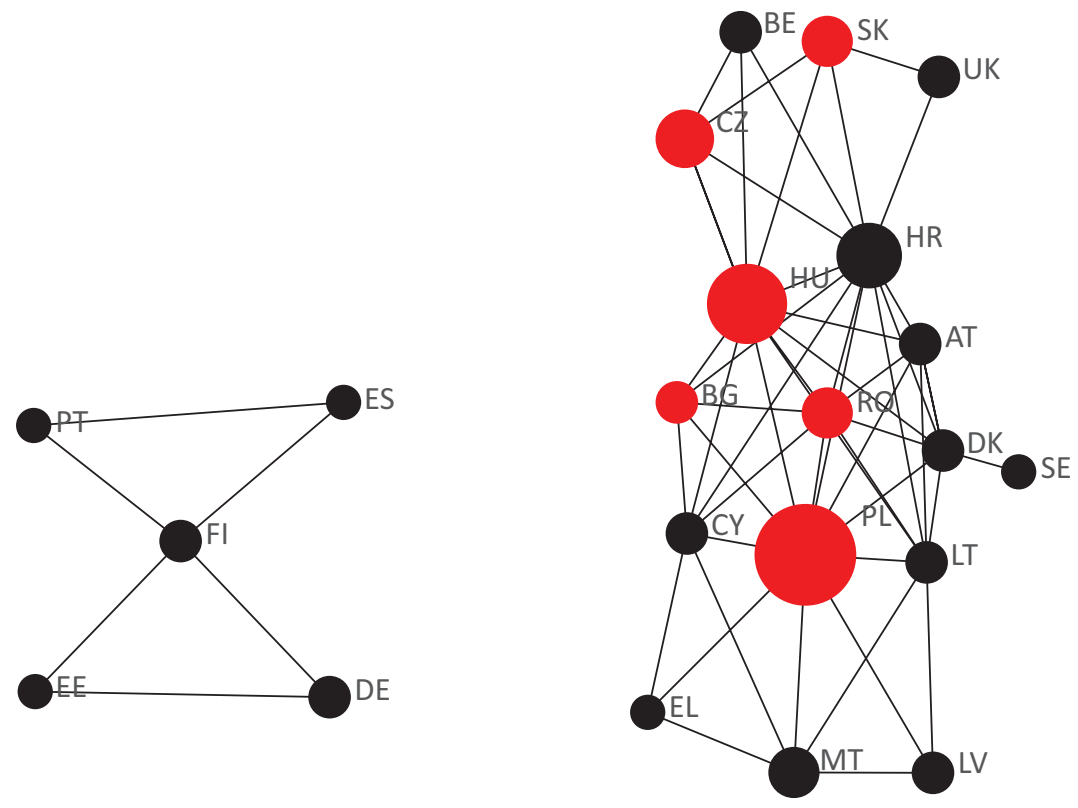

Figure 3. Coalitions of dissent in EU energy policies. Source: Authors' calculation based on data from the Monthly Summaries of Council Acts (https://www.consilium.europa.eu). The size of the nodes represents the number of dissenting votes. The graph was made with Ucinet 6 and NetDraw 2.1 software.

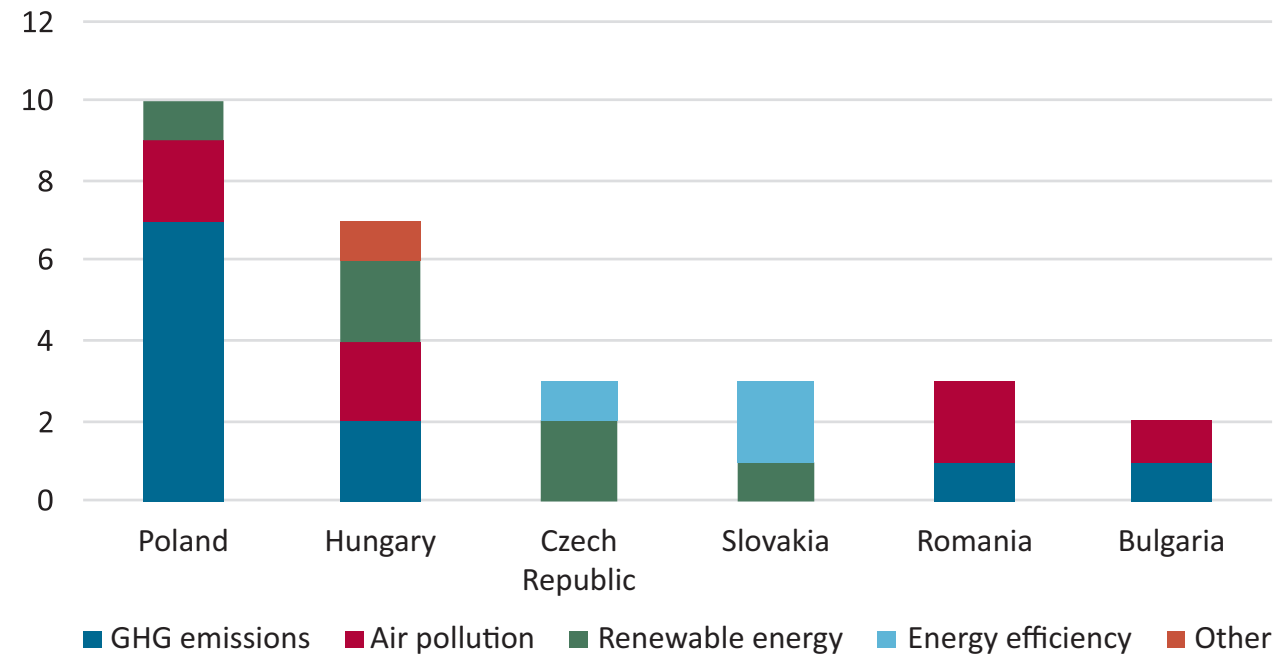

Figure 4. Dissenting votes of the six CEE countries by policy issue. Source: Authors' calculation based on Monthly Summary of Council Acts (https://www.consilium.europa.eu).

twice, once by Slovakia and once by Slovakia and the Czech Republic. In the category 'other', we include a regulation on the security of gas supply, opposed by Hungary.

Overall, three main observations can be made. First, there is an obvious pattern of varying voting behavior across different issue areas. Poland has been almost isolated in continuously dissenting from the majority position in the Council on GHG emissions reductions and ETS reform. With regard to air pollution, the situation is more mixed with other countries, particularly Bulgaria, Romania, and Hungary, objecting to the Council's majority position alongside Poland. The voting behavior of Slovakia and the Czech Republic is particularly telling given that the disagreements raised by these two countries have been in the areas of renewable energy and energy efficiency and do not match the voting pattern of the other four CEE countries. Overall, the homogeneity in voting behavior among the six CEE countries is low and, if anything, issue specific. Second, there is a clear trend of intensified objections raised by the six CEE governments on various EU energy policy legislative acts since 2013. Finally, while several different coalitions of CEE countries can be identified based on the specific issue area, it is worth noting that Poland and Hungary have been the two CEE countries which have most often voted in the same way in objection to the Council majority position. 


\subsection{Political-Economic Interests and Developments in the Energy Sectors in the Six CEE Countries}

Although partly or fully state-owned energy utilities still control significant shares of the market in Hungary, Poland, and Slovakia, many energy plants in CEE were privatized as part of the privatization wave in the 1990's and 2000's. The privatization trend has been reversing recently and there has been a marked revival of state interventions in the energy sector in the last decade through state acquisition of ownership over foreign energy companies, regulation of energy prices, and negotiation of large energy projects. This trend has been particularly apparent in Hungary and Poland, and to a lesser extent in Slovakia. In the Czech Republic, the state already owns the majority share of the CEZ company, which is a key regional market player in the electricity sector. In its energy strategy published in 2012, the Hungarian government announced that:

In the future we will make an effort to increase the involvement of the public sector in the energy economy, while obviously respecting competitive neutrality and the rules demanded by a democratic society. (Hungarian Ministry for National Development, 2012)

The Slovak prime minister Fico has also declared the ambition to re-seize control over the energy sector while criticizing the privatization of the energy power undertaken by the utility Slovenské elektrárne in 2006 (Reuters, 2017a). Such statements have been followed by concrete actions. In 2017, a Hungarian businessman close to Prime Minister Viktor Orbán, Lőrinc Mészáros, together with the Prague-based company EPH, bought shares of RWE and EnBW in Mátrai Erőmü, the country's largest lignite coal power plant (Reuters, 2017b). In electricity distribution, in 2017, the state-owned company NKM Nemzeti Közmúvek (formerly ENKSZ) completed the take-over of the distribution company Démász from the French energy utility EdF and acquired stakes in two other electricity distributors owned by the German utility RWE (Budapest Business Journal, 2017). In addition, the Hungarian government has introduced interventionist measures to cap energy prices below market levels (International Energy Agency, 2017). In 2015 in Slovakia, the Italian energy utility ENEL announced it was selling $66 \%$ of its shares in Slovenské elektrárne to the Czech company $\mathrm{EPH}$. The Slovak government maintained $34 \%$ of shares with the option to acquire majority ownership in the electric power utility once two new nuclear power reactors Mochovce 3 and 4 have been built (Velinger, 2015). The same developments have been witnessed in Poland since 2015, with four state-owned energy utilities acquiring ownership and control over production facilities previously owned by foreign companies (Reuters, 2018). The trend of an increasing state role in the energy sector has been, however, far less prominent in Bulgaria and Romania where foreign companies continue to play impor- tant role in the distribution and generation of electricity. The new Romanian energy strategy, for instance, has maintained the need for the state to preserve ownership over some energy utilities, but it also stresses the principle of market competition and clear division between the state as a regulator and as a shareholder (Ministerul Energiei, 2016).

Not only has the nature and scale of state intervention in the energy sector varied across CEE countriesthe material base and industrial interests in the energy sector have exhibited important differences as well. Poland, for instance, has by far the most carbon-intensive electricity sector in the EU owing to the overreliance of the energy industry on domestic coal (Moro \& Lonza, 2018). The Czech Republic ranks second in terms of the carbon intensity of its electricity sector (Moro \& Lonza, 2018) but, interestingly, the state-owned CEZ company which owns stakes in energy companies throughout the region supports a more stringent ETS system. This is due to the fact that CEZ is less carbon intensive than some other major energy companies in Europe; thus, higher carbon prices give the company a competitive advantage in the short- and medium-term (CEZ Group, 2018). Bulgaria and Romania rank third and fourth in terms of carbon intensity of electricity production, but their concerns are aggravated by the high carbon intensity of their heating sectors as well as weaker economic development, leading to a higher impact of increasing emissions standards on energy prices. Slovakia and Hungary have comparatively less carbon-intensive electricity due to the significant role of nuclear and hydropower in their energy $\operatorname{mix}$ (Moro \& Lonza, 2018).

The levels of electricity prices, one of the main factors of competitiveness among the six CEE economies, also display important differences. Concerning prices for households, in the first half of 2018, Bulgaria had the lowest prices while Czech Republic had the highest. For nonhouseholds, Slovakia had the highest electricity prices among the six CEE countries, which are above the EU average. The lowest non-household electricity prices are in Czech Republic followed by Bulgaria, Romania, Hungary, and Poland (Eurostat, 2018). The unusually high electricity prices in Slovakia are due to various factors including hidden subsidies for coal and nuclear power, renewable energy support, increasing carbon prices, and considerable imports of energy sources and electricity (Slovak Spectator, 2016). In Poland, the price of electricity for non-households has increased recently and is expected to be under further upward pressure due to rising carbon prices and reliance of the energy sector on coal as the dominant source (Energy Transition, 2018).

\section{Discussion}

The presented data on voting behavior shows that there is no strong coherence among the six CEE governments in their positioning on EU energy-related legislation, and it supports recent findings regarding the heterogenity 
in energy and climate policy preferences in the CEE region (Bocquillon \& Maltby, 2017). However, our assessment has not confirmed the existence of two blocks with Poland, Bulgaria, and Romania on one side, and Hungary, Slovakia, and Czech Republic on the other, as suggested by Bocquillon and Maltby (2017). The differentiation across issue areas reveals that a more issue-specific approach is necessary to acquire deeper insights into the voting behavior of the six CEE countires and possible motives behind it. If Poland, Bulgaria and Romania have displayed similar preferences, it has only been in the case of air pollution legislation, where they are also accompanied by Hungary. In the area of GHG emissions and ETS reform, Poland has been relatively isolated in its voting behavior, with only occasional support from Hungary, Bulgaria, and Romania. Slovakia and the Czech Republic have revealed themselves to be outliers in the group, with their oppostion in the Council primarily targeting energy efficiency and renewable energy legislations.

The differences in voting patterns across issue areas underline the importance of sector-specific domestic preferences. Domestic political-economic interests are particularly powerful in illuminating differences in the voting behavior of the six CEE governments in the area of GHG emissions and ETS reform. Poland has been the most concerned party due to its heavy reliance on domestic coal and has opposed virtually all decisions of the Council on this matter (see also Skjærseth, 2018). Other countries have expressed lesser concern while the Czech Republic and Slovakia have not objected to any of the legislation pieces in this field. The decisions of the Czech government not to oppose the ETS reform has been largely motivated by the increasing awareness of the state-owned energy utility CEZ that higher carbonprices can strengthen the company's competitiveness on the regional market (see also Jevnaker \& Wettestad, 2017). Bulgaria and Romania have received considerable concessions from the EU in terms of free carbon permits and additional funding for fossil-fuel district heating through the Modernization Fund, which successfully moderated their opposition to the ETS reform. Vested economic interests and governments' concerns about increasing energy prices can also account for the relatively broad coalition of countries opposing higher air pollution standards since most of the EU air pollution legislation targets medium and large combustion plants operated by large energy utilities.

The Czech Republic's reluctance towards renewable energy targets can be explained by CEZ's concentrated sectoral power and its clear preferences for protecting the market and developing nuclear energy. The Slovakian and Hungarian governments have also advanced their plans of using nuclear energy. While illiberal tendencies in Hungary have likely decreased the government's willingness to open the domestic energy market to foreign producers of renewable energy, the same has not occurred in Poland, whose government has not opposed the most recent renewable energy directive. Part of the explanation may lie in the strategic decision of major state and business actors in the energy sector. As previously mentioned, Hungary has initiated the construction of a nuclear power plant (Paks II), which should provide low-carbon electricity to satisfy domestic demand, while Polish decision-makers have increasingly been considering renewable energy, particularly onshore and offshore wind, in response to the rising costs of carbon emissions from coal (Energy Transition, 2018). Bulgaria and Romania also withstood from objecting to renewable energy legislation, which may be related to their less concentrated domestic energy business interests and higher openness to foreign investments in renewable energy.

\section{Conclusions}

This article has set out to explore the question of whether the six CEE countries have exhibited common voting behavior on EU energy legislative acts in the Council in the period 2007-2018. We also examined the extent to which domestic institutions and actors (and their preferences) can account for the voting patterns of countries across different energy policy areas, and what conclusions can be drawn from this to inform EU decision-making and the future prospects of the EU energy union and decarbonization efforts. Five important contributions to the literature and policy-oriented research emerged from this analysis.

First, we have shown that, although the overall frequency of dissenting votes by the six CEE countries on energy legislative acts has increased in recent years, voting coalitions have varied across policy issues. There was no common blocking coalition among the six CEE countries in the Council on the latest legislative pieces of the EU energy and climate framework for 2030, which facilitated the political agreement for their adoption. Our findings support evidence about differences in energy interests among CEE countries advanced in recent studies (Bocquillon \& Maltby, 2017; Nosko \& Mišík, 2017), but provide more nuanced insights into the variation of voting and coalition patterns across major EU energy policy issues.

Second, we have illustrated the importance of domestic state-market structures in affecting voting behavior. While caution is necessary while drawing conclusions about the possible influence of domestic interests on voting behavior given the lack of empirical data and variety of factors at play, several important trends and plausible explanations have been suggested. Although all six CEE countries are dependent on fossil-fuels, the extent of this dependence and the interests and abilities of domestic energy companies to reap benefits from the decarbonization process have led to different government positions, as voting records on the ETS reform illustrates. Furthermore, we have highlighted the important trend of increasing statism in the energy sectors associated with the illiberal turn in several CEE countries. While this trend is motivated by the protection of domestic energy com- 
panies and provision of cheaper energy prices, we have not found a uniform immediate impact of this trend on voting behavior. Poland and Hungary, the two countries forming the region's 'illiberal avant-garde', have indeed displayed the most similar voting pattern among the six CEE countries, but this trend has weakened recently, as the case of the new Renewable Energy Directive shows. We have proposed that the differences in strategic energy planning at the national level may account for this, with Poland showing higher interest in renewable energy as an alternative to increasingly costly coal-based electricity. These findings underline the necessity of paying closer attention to sectoral preferences (Mühlböck \& Tosun, 2017), as well as their interplay with EU policy over time, in order to understand policy change and national governments' preferences towards EU legislation.

Thirdly, our results confirm the growing trend of contestation voting in the Council, already identified in other EU policy areas such as justice and home affairs (Roos, 2018). Even if political divisions regarding EU energy policies are intensifying, this does not necessarily lead to gridlock or stagnation in the process of widening and deepening of EU energy policy, especially in climate-related energy policy areas. Our analysis suggests that shifting national preferences and weak issuespecific coalitions within the six CEE countries have facilitated further EU integration.

Fourth, the step up in the ambition of the EU energy and climate policy package 2030, from the Guideline given by the European Council in 2014 to the final formulation and adoption of the legislation in 2018, somewhat downplays the prevailing notion about the increasingly decisive role of top-level negotiations in the European Council for EU decision-making (Bocquillon \& Dobbels, 2014).

Finally, and related to the previous point, it is worth noting that the dissenting votes and written concerns on the new EU Energy Efficiency Directive and Renewable Energy Directive came not only from some of the six CEE governments (Czech Republic, Slovakia, and Hungary), but also from member states including Belgium, Portugal, and Germany (Council of the EU, 2018b, 2018c). This indicates that individual national governments find it increasingly difficult to influence the EU decision-making process on energy issues and are faced with high adaptation pressure. This may open up possibilities for a positive policy feedback loop and deeper structural changes. For example, the increasing $\mathrm{CO}_{2}$ price through the reformed ETS has already placed fossil-fuel industries and interests under pressure, leading governments and businesses to explore opportunities in low-carbon sectors. The ability of relevant actors to link the benefits from new lowcarbon technologies to domestic objectives, such as job creation, energy security, and decarbonization, will significantly affect the prospect of national clean energy transitions. The recent emphasis on residential solar PV in the energy strategies of Hungary and the Czech Republic (Czech Ministry of Industry and Trade, 2014; Hungar- ian Ministry of National Development, 2012), which resonate well with the goals of economic patriotism and domestic value creation, shows the variety of possible policy framings which can facilitate domestic clean energy transitions. On a more cautious note, the increasing role of the state coupled with traditionally closed energy policy communities and democratic backsliding in several CEE countries might hinder clean energy transition efforts and EU energy market integration while strengthening the prospects for established energy sources such as nuclear energy.

\section{Acknowledgments}

This work was supported by the German Research Foundation (DFG) and the Technical University of Munich within the Open Access Publishing Funding Programme. We thank Miranda Schreurs and Fiona Kinniburgh for their helpful comments on the paper. We also thank the anonymous reviewers for their constructive feedback.

\section{Conflict of Interests}

The authors declare no conflict of interests.

\section{References}

Appel, H., \& Orenstein, M. A. (2018). From triumph to crisis: Neoliberal economic reform in postcommunist countries. Cambridge: Cambridge University Press.

Bailer, S., Mattila, M., \& Schneider, G. (2015). Money makes the EU go round: The objective foundations of conflict in the Council of Ministers. JCMS: Journal of Common Market Studies, 53(3), 437-456.

Bocquillon, P., \& Dobbels, M. (2014). An elephant on the 13th floor of the Berlaymont? European Council and Commission relations in legislative agenda setting. Journal of European Public Policy, 21(1), 20-38.

Bocquillon, P., \& Maltby, T. (2017). The more the merrier? Assessing the impact of enlargement on EU performance in energy and climate change policies. East European Politics, 33(1), 88-105.

Börzel, T. A., \& Buzogány, A. (2019). Compliance with EU environmental law: The iceberg is melting. Environmental Politics. https://doi.org/10.1080/ 09644016.2019 .1549772

Braun, M. (2014). Europeanization of environmental policy in the new Europe: Beyond conditionality. Farnham: Ashgate Publishing.

Budapest Business Journal. (2017). State utilities to hold natural gas, electricity distributors. Budapest Business Journal. Retrieved from https://bbj.hu/ economy/state-utility-to-hold-natl-gas-electricity-dis tributors 134286

Buzogány, A. (2017). Illiberal democracy in Hungary: Authoritarian diffusion or domestic causation? Democratization, 24(7), 1307-1325.

CEZ Group. (2018). CEZ Group: The leader in power mar- 
kets of Central and Southeastern Europe. Prague: CEZ Group. Retrieved from https://www.cez.cz/edee/ content/file/investori/2018-05-investment-story.pdf

Ćetković, S., \& Buzogány, A. (2016). Varieties of capitalism and clean energy transitions in the European Union: When renewable energy hits different economic logics. Climate Policy, 16(5), 642-657.

Council of the European Union. (2018a). Governance of the Energy Union: Council confirms deal reached with the European Parliament. Council of the European Union. Retrieved from https://www.consilium. europa.eu/en/press/press-releases/2018/06/29/gov ernance-of-the-energy-union-council-confirms-dealreached-with-the-european-parliament

Council of the European Union. (2018b). Draft directive of the European Parliament and of the Council amending directive 2012/27/EU on energy efficiency (first reading): Adoption of the legislative act, statements. Brussels: Council of the European Union. Retrieved from http://data.consilium.europa.eu/ doc/document/ST-14281-2018-ADD-1/en/pdf

Council of the European Union. (2018c). Draft proposal for a directive of the European Parliament and of the Council on the promotion of the sue of energy from renewable sources (first reading): Adoption of the legislative act, statements. Brussels: Council of the European Union. Retrieved from http://data. consilium.europa.eu/doc/document/ST-14286-2018ADD-1/en/pdf

Energy Transition. (2018). Offshore wind rising to challenge king coal in Polish energy market. Energy Transition. Retrieved from https://energytransition. org/2018/07/offshore-wind-rising-to-challenge-kingcoal-in-polish-energy-market

European Parliament. (2018a). Energy Union: Deals on efficiency targets and governance. European Parliament. Retrieved from http://www.europarl.europa. eu/news/en/press-room/20180619IPR06146/energyunion-deals-on-efficiency-targets-and-governance

European Parliament. (2018b). Energy: new target of $32 \%$ from renewables by 2030 agreed by MEPs and ministers. European Parliament. Retrieved from http://www.europarl.europa.eu/news/de/press-room /20180614IPR05810/energy-new-target-of-32-fromrenewables-by-2030-agreed-by-meps-and-ministers

Eurostat. (2018). Electricity prices statistics. Eurostat. Retrieved from https://ec.europa.eu/eurostat/stat istics-explained/index.php/Electricity_price_statistics

General Secretariat of the Council. (2014). European Council conclusions. Brussels: European Council. Retrieved from https://www.consilium.europa.eu/ uedocs/cms_data/docs/pressdata/en/ec/145397.pdf

Hagemann, S., \& de Clerck-Sachsse, C. (2007). Old rules, new game: Decision-making in the Council of Ministers after the 2004 enlargement. Brussels: Centre for European Policy Studies.

Hagemann, S., Hobolt, S. B., \& Wratil, C. (2017). Government responsiveness in the European Union: Ev- idence from Council voting. Comparative Political Studies, 50(6), 850-876.

Hertz, R., \& Leuffen, D. (2011). Too big to run? Analysing the impact of enlargement on the speed of EU decision-making. European Union Politics, 12(2), 193-215.

Hosli, M. O., Mattila, M., \& Uriot, M. (2011). Voting in the Council of the European Union after the 2004 enlargement: A comparison of old and new member states. JCMS: Journal of Common Market Studies, 49(6), 1249-1270.

Høyland, B., \& Hansen, V. W. (2013). Issue-specific policypositions and voting in the Council. European Union Politics, 15(1), 59-81.

Hungarian Ministry for National Development. (2012). National energy strategy 2030. Budapest: Ministry for National Development. Retrieved from http:// 2010-2014.kormany.hu/download/7/d7/70000/Hun garian\%20Energy\%20Strategy\%202030.pdf

Innes, A. (2016). Corporate state capture in open societies: The emergence of corporate brokerage party systems. East European Politics and Societies, 30(3), 594-620.

International Energy Agency. (2017). Hungary 2017 review. Paris: IEA Publications. https://euagenda.eu/ upload/publications/untitled-94763-ea.pdf

Jevnaker, T., \& Wettestad, J. (2017). Ratcheting up carbon trade: The politics of reforming EU emissions trading. Global Environmental Politics, 17(2), 105-124.

Jörgens, H., \& Solorio, I. (2017). A Guide to EU renewable energy policy. Cheltenham: Edward Elgar.

Katzenstein, P. J. (1976). International relations and domestic structures: Foreign economic policies of advanced industrial states. International Organization, 30(1), 1-45.

Kern, F. (2011). Ideas, institutions, and interests: Explaining policy divergence in fostering 'system innovations' towards sustainability. Environment and Planning-Part C, 29(6), 1117-1137.

König, T., \& Junge, D. (2009). Why don't veto players use their power? European Union Politics, 10(4), 507-534.

Lockwood, M., Kuzemko, C., Mitchell, C., \& Hoggett, R. (2017). Historical institutionalism and the politics of sustainable energy transitions: A research agenda. Environment and Planning C: Politics and Space, 35(2), 312-333.

Mattila, M. (2004). Contested decisions: Empirical analysis of voting in the European Union Council of Ministers. European Journal of Political Research, 43(1), 29-50.

Mattila, M. (2009). Roll call analysis of voting in the European Union Council of Ministers after the 2004 enlargement. European Journal of Political Research, 48(6), 840-857.

Ministerul Energiei. (2016). Strategia Energetică a României 2016-2030, cu perspectiva anului 2050 
[Romania's energy strategy 2016-2030, with a perspective to 2050]. Bucharest: Ministerul Energiei. Retrieved from http://www.mmediu.gov.ro/app/ webroot/uploads/files/2017-03-02_Strategia-Energe tica-a-Romaniei-2016-2030.pdf

Mišík, M. (2015). The influence of perception on the preferences of the new member states of the European Union: The case of energy policy. Comparative European Politics, 13(2), 198-221.

Mišík, M. (2017). Comments on "the Energy Union and security-of-gas supply" by Ole Gunnar Austvik. Energy Policy, 102, 27-29.

Moravcsik, A. (1993). Preferences and power in the European Community: A liberal intergovernmentalist approach. JCMS: Journal of Common Market Studies, 31(4), 473-524.

Moro, A., \& Lonza, L. (2018). Electricity carbon intensity in European Member States: Impacts on GHG emissions of electric vehicles. Transportation Research Part D: Transport and Environment, 64(1), 5-14.

Mühlböck, M., \& Tosun, J. (2017). Responsiveness to different national interests: Voting behaviour on genetically modified organisms in the Council of the European Union. JCMS: Journal of Common Market Studies, 56(2), 385-402.

Naurin, D. (2018). Liberal intergovernmentalism in the Councils of the EU: A baseline theory? JCMS: Journal of Common Market Studies, 56(7), 1526-1543.

Nosko, A., \& Mišík, M. (2017). No united front: The political economy of energy in Central and Eastern Europe. In S. Andersen, G. Andreas, \& N. Sitter (Eds.), Energy Union (pp. 201-222). London: Palgrave.

Nölke, A., \& A. Vliegenthart (2009). Enlarging the varieties of capitalism: The emergence of dependent market economies in East Central Europe. World Politics, 61(4), 670-702.

Parízek, M., Hosli, M. O., \& Plechanovová, B. (2015). Avoiding paralysis: The Eastern enlargement and the Council of the European Union. Journal of European Integration, 37(6), 649-665.

Reuters. (2017a). Slovakia, seeking control over energy sector, considers state holding company. Reuters. Retreived from https://www.reuters.com/article/usslovakia-energy/slovakia-seeking-control-over-energy -sector-considers-state-holding-company-idUSKBN18 $72 \mathrm{Al}$

Reuters. (2017b). Hungarian-Czech group buys majority stake in Matrai power plant. Reuters. Retrieved from https://af.reuters.com/article/energyOilNews/idAFL 8 N1OE41E

Reuters. (2018). Polish state has too much control over energy: Regulator. Reuters. Retrieved from https:// www.reuters.com/article/us-poland-energy/polish- state-has-too-much-control-over-energy-regulator-id USKCN1IQ1JP

Roos, C. (2018). Opposition or consensus in the Justice and Home Affairs Council? The how and why of increasing member state contestation over EU policy. Journal of European Integration, 38(4), 1-18.

Scheiring, G. (2018). Lessons from the political economy of authoritarian capitalism in Hungary. Amsterdam: Transnational Institute.

Schreurs, M. A., \& Tiberghien, Y. (2007). Multi-level reinforcement: Explaining European Union leadership in climate change mitigation. Global Environmental Politics, 7(4), 19-46.

Skjærseth, J. B. (2016). Linking EU climate and energy policies: Policy-making, implementation and reform. International Environmental Agreements: Politics, Law and Economics, 16(4), 509-523.

Skjærseth, J. B. (2018). Implementing EU climate and energy policies in Poland: Policy feedback and reform. Environmental Politics, 27(3), 498-518. doi:10.1080/ 09644016.2018.1429046

Skjærseth, J. B., Eikeland, P. O., Gulbrandsen, L. H., \& Jevnaker, T. (2016). Linking EU climate and energy policies: Decision-making, implementation and reform. Cheltenham: Edward Elgar Publishing.

Skogstad, G. (2017). Policy feedback and self-reinforcing and self-undermining processes in EU biofuels policy. Journal of European Public Policy, 24(1), 21-41.

Slovak Spectator. (2016). Study critical of extra fees for electricity. Slovak Spectator. Retrieved from https://spectator.sme.sk/c/20079865/study-criticalof-extra-fees-for-electricity.html

Szulecki, K., Fischer, S., Gullberg, A. T., \& Sartor, O. (2016). Shaping the 'Energy Union': Between national positions and governance innovation in EU energy and climate policy. Climate Policy, 16(5), 548-567.

Toshkov, D. D. (2017). The impact of the Eastern enlargement on the decision-making capacity of the European Union. Journal of European Public Policy, 24(2), 177-196.

Velinger, J. (2015). EPH seals Slovenské elektrárne purchase, but Slovak government still seeking control. Czech Radio. Retrieved from https://www.radio.cz/ en/section/business/eph-seals-slovenske-elektrarnepurchase-but-slovak-government-still-seeking-control

Visegrad Group. (2014). Joint paper on the EU climate and energy framework 2020-2030. Retrieved from http://www.visegradgroup.eu/download.php?docID $=261$

Ydersbond, I. M. (2018). Power through Collaboration: Stakeholder influence in EU climate and energy negotiations. International Negotiation, 23(3), 478-514. 


\section{About the Authors}

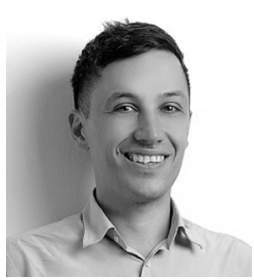

Stefan Ćetković is a Post-Doc at the Environmental and Climate Policy Chair at the Bavarian School of Public Policy, Technical University of Munich. He holds a PhD from Freie Universität Berlin and has more than ten years of experience as advisor, lecturer and researcher in the areas of EU policy, sustainability transition, and comparative climate and energy policy and politics.

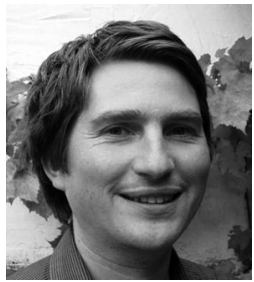

Aron Buzogány works as a Researcher at the Institute of Forest, Environmental and Natural Resource Policy, University of Natural Resources and Life Sciences (BOKU), Vienna, Austria. He holds a PhD from Freie Universität Berlin and has held academic positions at Freie Universität, Yale University, the German Public Administration Institute and the University of Munich. His research focuses on comparative politics and policymaking in the European Union, with a policy focus on environmental and energy policies. 


\section{Appendix}

1. Regulation (EC) No 715/2007 of the European Parliament and of the Council of 20 June 2007 on type approval of motor vehicles with respect to emissions from light passenger and commercial vehicles (Euro 5 and Euro 6 ) and on access to vehicle repair and maintenance information.

2. Regulation (EC) No 106/2008 of the European Parliament and of the Council of 15 January 2008 on a Community energyefficiency labelling programme for office equipment (recast version).

3. Regulation (EC) No 1005/2009 of the European Parliament and of the Council of 25 March 2009 on substances that deplete the ozone layer (recast).

4. Council Decision 2010/787/EU of 10 December 2010 on State aid to facilitate the closure of uncompetitive coal mines 16229/1/10 REV 1.

5. Directive 2012/33/EU of the European Parliament and of the Council of 21 November 2012 amending Council Directive $1999 / 32 / E C$ as regards the sulphur content of marine fuels.

6. Directive 2012/27/EU of the European Parliament and of the Council of 25 October 2012 on energy efficiency, amending Directives 2009/125/EC and 2010/30/EU and repealing Directives 2004/8/EC and 2006/32/EC.

7. Decision No 1386/2013/EU of the European Parliament and of the Council of 20 November 2013 on a General Union Environment Action Programme to 2020 'Living well, within the limits of our planet'.

8. Decision No 1359/2013/EU of the European Parliament and of the Council of 17 December 2013 amending Directive $2003 / 87 /$ EC clarifying provisions on the timing of auctions of greenhouse gas allowances.

9. Decision No 377/2013/EU of the European Parliament and of the Council of 24 April 2013 derogating temporarily from Directive 2003/87/EC establishing a scheme for greenhouse gas emission allowance trading within the Community.

10. Directive 2015/1513/EU of the European Parliament and of the Council of 9 September 2015 amending Directive 98/70/EC relating to the quality of petrol and diesel fuels and amending Directive 2009/28/EC on the promotion of the use of energy from renewable sources.

11. Regulation (EU) 2015/757 of the European Parliament and of the Council on the monitoring, reporting and verification of carbon dioxide emissions from maritime transport, and amending Directive 2009/16/EC.

12. Directive 2015/2193/EU of the European Parliament and of the Council of 25 November 2015 on the limitation of emissions of certain pollutants into the air from medium combustion plants.

13. Decision No 2015/1814/EU of the European Parliament and of the Council of 6 October 2015 concerning the establishment and operation of a market stability reserve for the Union greenhouse gas emission trading scheme and amending Directive 2003/87/EC.

14. Directive 2016/2284/EU of the European Parliament and of the Council of 14 December 2016 on the reduction of national emissions of certain atmospheric pollutants, amending Directive 2003/35/EC and repealing Directive 2001/81/EC.

15. Regulation (EU) 2016/1952 of the European Parliament and of the Council of 26 October 2016 on European statistics on natural gas and electricity prices and repealing Directive 2008/92/EC.

16. Regulation (EU) 2017/852 of the European Parliament and of the Council of 17 May 2017 on mercury, and repealing Regulation (EC) No 1102/2008.

17. Regulation (EU) $2017 / 1938$ of the European Parliament and of the Council of 25 October 2017 concerning measures to safeguard the security of gas supply and repealing Regulation (EU) No 994/2010.

18. Directive (EU) $2018 / 410$ of the European Parliament and of the Council of 14 March 2018 amending Directive 2003/87/EC to enhance cost-effective emission reductions and low-carbon investments, and Decision (EU) 2015/1814. 
19. Regulation (EU) 2018/841 of the European Parliament and of the Council of 30 May 2018 on the inclusion of greenhouse gas emissions and removals from land use, land use change and forestry in the 2030 climate and energy framework, and amending Regulation (EU) No 525/2013 and Decision No 529/2013/EU.

20. Regulation (EU) 2018/842 of the European Parliament and of the Council of 30 May 2018 on binding annual greenhouse gas emission reductions by Member States from 2021 to 2030 contributing to climate action to meet commitments under the Paris Agreement and amending Regulation (EU) No 525/2013.

21. Directive (EU) 2018/844 of the European Parliament and of the Council of 30 May 2018 amending Directive 2010/31/EU on the energy performance of buildings and Directive 2012/27/EU on energy efficiency.

22. Directive of the European Parliament and of the Council amending Directive 2012/27/EU on energy efficiency.

23. Directive of the European Parliament and of the Council on the promotion of use of renewable energy sources (recast). 